\title{
Performance of a driven hitch-cart for draft animal power under different power take-off torque and ballast levels condition
}

\author{
Piernicola Masella, Lorenzo Guerrini, Alessandro Parenti, Fabio Baldi, Paolo Spugnoli \\ Department of Agricultural, Food and Forestry Systems, University of Firenze, Firenze, Italy
}

\begin{abstract}
The performance of a two-wheel driven hitch-cart designed for draft animal power has been assessed. The cart fits a three-point linkage system and a ground-driven power take-off (PTO). Conventional pneumatic tires and metallic wheels have been tested in dedicated draft trials with increasing torque applied to PTO $(7.0$ to $70 \mathrm{Nm})$ at two ballast levels (100 and $200 \mathrm{~kg}$ ). Draft force varies from a minimum of about $760 \mathrm{~N}$ (pneumatic tires and the lowest ballast), up to about $4480 \mathrm{~N}$ (metallic wheels and the highest ballast), with a linear increase as a function of the PTO applied torque. In term of global efficiency the better performances was achieved in different conditions. The metallic wheels deliver greater power to the PTO than pneumatic tires. Furthermore, they had global efficiencies higher than pneumatic for high power requirements, while the pneumatics perform better when the required power is low. Slippage rises as a function of increasing torque and decreasing ballast, with metallic wheels allowing delivery of greater PTO torque at the same slippage extent. The performances of the cart are consistent with the use of implements designed for small tractors.
\end{abstract}

\section{Introduction}

In the twenty-first century draft animal power (DAP) still remain of crucial importance in developing countries. In fact animal power is

\footnotetext{
Correspondence: Lorenzo Guerrini, Department of Agricultural, Food and Forestry Systems (GESAAF), University of Firenze, piazzale delle Cascine 15, 50144 Firenze, Italy.

Tel.: +39.0553 .288352 - Fax: +39.0553 .288316 .

E-mail: lorenzo.guerrini@unifi.it
}

Key words: Animal traction; hitch-cart; biodynamic farming; sustainable agriculture.

Received for publication: 19 January 2016.

Accepted for publication: 25 July 2016.

(C) Copyright P. Masella et al., 2016

Licensee PAGEPress, Italy

Journal of Agricultural Engineering 2016; XLVII:538

doi:10.4081/jae.2016.538

This article is distributed under the terms of the Creative Commons Attribution Noncommercial License (by-nc 4.0) which permits any noncommercial use, distribution, and reproduction in any medium, provided the original author(s) and source are credited. widespread in Asia and Latin America, and is expanding in Africa (AGS, 2010; Fuller and Aye, 2012). Surprisingly, a renewed interest for DAP is recently grown in developed countries, spanning from USA to the European modern agricultural systems relying in the context of organic and biodynamic farming. According to some published papers, DAP could be the next step in an ecological, earth-friendly farming system (Rydberg and Jansén, 2002; Mumma, 2008; Leslie, 2013; Mulder and Dube, 2014). This renewed focus is mirrored in the scientific literature by studies underlining the belonging of DAP to the renewable energy sources and focusing on the environmental effects of reintroducing DAP in modern highly mechanised agriculture (Spugnoli and Dainelli, 2013; Cerruti et al., 2014). Indeed, one of the technological solution already developed for DAP is represented by the so-called hitch-carts. They are a range of wheeled tool-carriers that could be used for various agricultural operations. As reviewed by Joubert (2000) the more sophisticated models consist of three or four wheels chassis, a three-point linkage system and a ground-drive power takeoff (PT0), allowing the use of a wide range of conventional small size tractor mounted implements. Particularly, these carts can be used for ploughing, harrowing, planting, rolling, cultivating, fertiliser distributing, boom spraying, mowing, racking, and baling. Starkey (1988) stated the broad failure of these devices in the developing countries, mainly because of the technological inappropriateness to the realities of these environments, high operating costs, difficult of finding spare parts and suitable implements. Certainly, all of this does not hold in the realities of developed countries, where organic and biodynamic farms have the potential to use relatively advanced and expensive technologies. In other words, in the latter realities the use of hitchcarts appears a suitable solution to improve DAP work efficiencies. In a previous work, the field performances of a two wheels DAP hitch-cart equipped with a ground-driven PTO system (in the following referred as driven hitch-cart) were characterised (Spugnoli et al., 2008). One of the main findings of that research underlines the importance of wheels slippage, which occurs when increasing the PTO applied torque depending on wheel soil adherence, and suggesting the possible use of metallic wheels as a mean to overcome this problem. Following these evidences, a set of purposely-designed metallic wheels has been realised and tested in a series of dedicated field trials. The results of such experiment are presented in this paper. These information gain importance in the context of modern agricultural systems for an efficient and renewed exploitation of DAP.

\section{Materials and methods}

\section{The driven hitch-cart}

A cart belonging to the category one hitch-cart as defined by Joubert (2000), has been tested. The cart has two wheels (namely driven hitch-cart; Figures $1 \mathrm{~A}$ and 2) and was equipped with a three-point linkage system and a ground-driven PTO. The main frame of the driven 
hitch-cart consists of a trapezoidal chassis of square section steel tubes, mounting the three point linkage system, supports for harnessing, the driver's seat, and part of the gearing transmission going from wheels to the PTO. The three-point linkage is fitted with a manually operated hydraulic pump placed close to the driver seat. The chassis is mounted on a two wheels rear-axe equipped with a differential gear box. The wheels fit pneumatic tires (measuring 6.50-14, width of 175 $\mathrm{mm}$ ), corresponding to a whole track of $1750 \mathrm{~mm}$. The whole length of the driven hitch-cart was $1400 \mathrm{~mm}$, with a height of $680 \mathrm{~mm}$ at the driver's seat. The empty weight is $175 \mathrm{~kg}$. A peculiarity of the driven hitchcart is the ground-driven PT0, where the motion is derived from wheels via the differential, connected to a simple sprocket-chain drive system, and a rigid joint (tooth clutch), which allows by a specific lever, to transmit power to the PTO shaft when required or unplugging when unnecessary (manoeuvres, shifting etc.). The overall transmission ratio corresponds to 15.75 , so that assuming a forward speed of $1 \mathrm{~m} \mathrm{~s}^{-1}$ (i.e., the average working speed of a horse), a PT0 speed value of about $519 \mathrm{rpm}$ is obtained, representing the theoretical number of revolutions in absence of slippage and for wheels fitting tires with a rolling radius of $290 \mathrm{~mm}$.

\section{The metallic wheels}

A set of two handcrafted metallic wheels, whose technical specifications are summarised in Table 1, was purposely designed for this experiment. Briefly, eighteen steel tubes measuring $76 \mathrm{~mm}$ external diameter and $165 \mathrm{~mm}$ length (thickness $2 \mathrm{~mm}$ ), were fixed around a standard tire rim (390 mm external diameter, $165 \mathrm{~mm}$ width). Afterward, two annular flat rings were fixed around the tubes giving support for lugs. The latter, were realised with an L-shaped mild steel profile, measuring $25 \times 25 \mathrm{~mm}$, thickness $2 \mathrm{~mm}$. Eighteen lugs were fixed on the annular rings with a circumferential angle of $18.9^{\circ}$ and a lug angle of $0^{\circ}$. Figure 1 presents a picture of the metallic wheel (Figure 1B).

\section{Experimental procedure}

For the purpose of our experiment we assume that a potential use of the cart could be light working operation for the management of fruit orchards, such as spraying, topping, and inter-row mowing. In these cases the inter row grassing is commonly applied. However, under this soil conditions the wheel slippage could be a potential limit for a proper use of the driven hitch-carts (Spugnoli et al., 2008). Thus the trials were performed on turf soil in an apple orchard inter-row. The soil char- acteristics were: bulk density $1.27 \mathrm{Mg} \mathrm{m}^{-3}$; moisture content $29.21 \%$; cone index $1.78 \mathrm{MPa}$; sand $35 \%$, silt $32 \%$, clay $33 \%$. The soil was fully covered by grass (average height $89.5 \mathrm{~mm}$, standard deviation 22.6) and the turf composition was: grass - ryegrass (Lolium spp.); meadow grass (Poa spp.); tall fescue (Festuca spp.); other species. Pneumatic tires and metallic wheels were compared in twenty draft trials, by loading the hitch-cart at two levels of ballast (100 and $200 \mathrm{~kg}, 10$ trials each, by means of an appropriate numbers of $25 \mathrm{~kg}$ sandbags), and increasing torque applied to the PTO in the range of about 7 to $70 \mathrm{Nm}$, in five incrementing steps per each ballast-wheels combination. At this purpose, the PTO was fitted with a previously calibrated hydraulic disc brake, in order to simulate the torque resistance given by driven implements. To balance the higher weight of metallic wheels than pneumatic tires, a subsidiary ballast of $34.2 \mathrm{~kg}$ (as a water filled tank) was loaded on the hitch-cart (Figure 1). Draft trials were performed on a $50 \mathrm{~m}$ long track.

The driven hitch-cart was pulled by a 4WD vehicle (model Defender 90 , Land Rover, UK) at a forward speed of about $1 \mathrm{~m} \mathrm{~s}^{-1}$, simulating the conventional draft of a working horse. The following parameters were recorded during each trial: forward speed (by measuring time to travel

Table 1. Specifications of metallic wheels.

\begin{tabular}{lc}
\hline Parameter & Sire \\
Outer diameter & $602 \mathrm{~mm}$ \\
Outer width & $227 \mathrm{~mm}$ \\
\hline Rim diameter & $390 \mathrm{~mm}$ \\
Rim width & $165 \mathrm{~mm}$ \\
\hline Annular rings thickness & $5 \mathrm{~mm}$ \\
Annular rings width & $30 \mathrm{~mm}$ \\
\hline Lugs spacing & $20^{\circ}$ \\
Lugs made from mild steel L-shaped size & $25 \mathrm{~mm}$ height, \\
& $25 \mathrm{~mm}$ width, $2 \mathrm{~mm}$ thick \\
\hline Lugs length & $250 \mathrm{~mm}$ \\
Lugs circumferential angle & $18.9^{\circ}$ \\
\hline Lugs angle & $0^{\circ}$ \\
Weight & $34.18 \mathrm{daN}$ \\
\hline
\end{tabular}
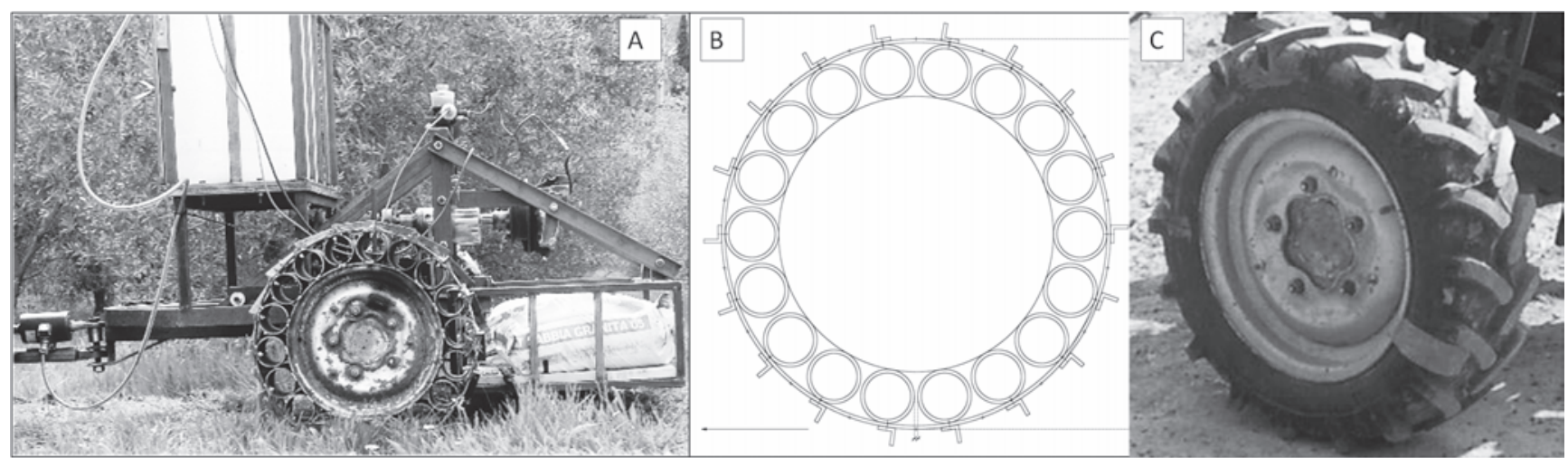

Figure 1. A) The driven hitch-cart; B) sketch of the metallic wheel; C) the pneumatic tire. 
the 50 meter track), draft force (by a strain gauge load cell, model U3G1, BLH Vishay Measurements Group GmbH, Germany, response $3 \mathrm{mV} \mathrm{V}{ }^{-1}$, F.S. $50 \mathrm{kN}$ ), torque applied to PTO and PTO rotational speed [by a BCS, (Italy) rotating torque/speed transducer, model MD 200, response $1.92 \mathrm{mV} \mathrm{V}^{-1}$, F.S. $250 \mathrm{Nm}$ ], number of wheels actual revolutions (by visual direct observation, i.e., by counting the actual wheel revolutions). Two independent observations for each test were recorded for the forward speed and number of wheels actual revolutions, and the average value was taken. The load cell and the torque/speed transducer were fitted to a data acquisition system based on a modular multichannel data logger (model MCDR-M-128, Leane international, Italy) fitted to a laptop computer (MCDR128 acquisition software). The acquisition system was calibrated before every test to avoid any possibility of error attributable to jerks.

\section{Data analysis}

The driven hitch-cart acts as a reverse traction device, where the input power comes from the draft force of pulling, and the output power comes from the torque available at the PTO shaft. Therefore, the global efficiency (GE) of the driving hitch-cart may be defined as:

$\mathrm{GE}=\mathrm{W}_{\text {out }} / \mathrm{W}_{\text {in }}$

where $\mathrm{W}_{\text {out }}$ stay for the output power, $\mathrm{W}_{\text {in }}$ stay for the input power.

The input power $\mathrm{W}_{\text {in }}$ was computed as product of the measured draft force and the observed forward speed. The output power was computed as product of the measured PTO torque and the PTO rotation speed. According to Wong (1978), GE corresponds to:

\section{$\mathrm{GE}=\mathrm{TE}^{*} \mathrm{ME}^{*} \mathrm{SE}$}

where TE is the gears transmission efficiency, ME is the motion efficiency, SE is the slip efficiency.

Assuming a reasonable value for transmission efficiency of 0.88 (corresponding to the overall efficiency of the differential gear box and the sprocket-chain drive system; Stout and Cheze, 1999), Equation 2 can be solved as:

$\mathrm{ME}=\mathrm{GE} /(0.88 * \mathrm{SE})$
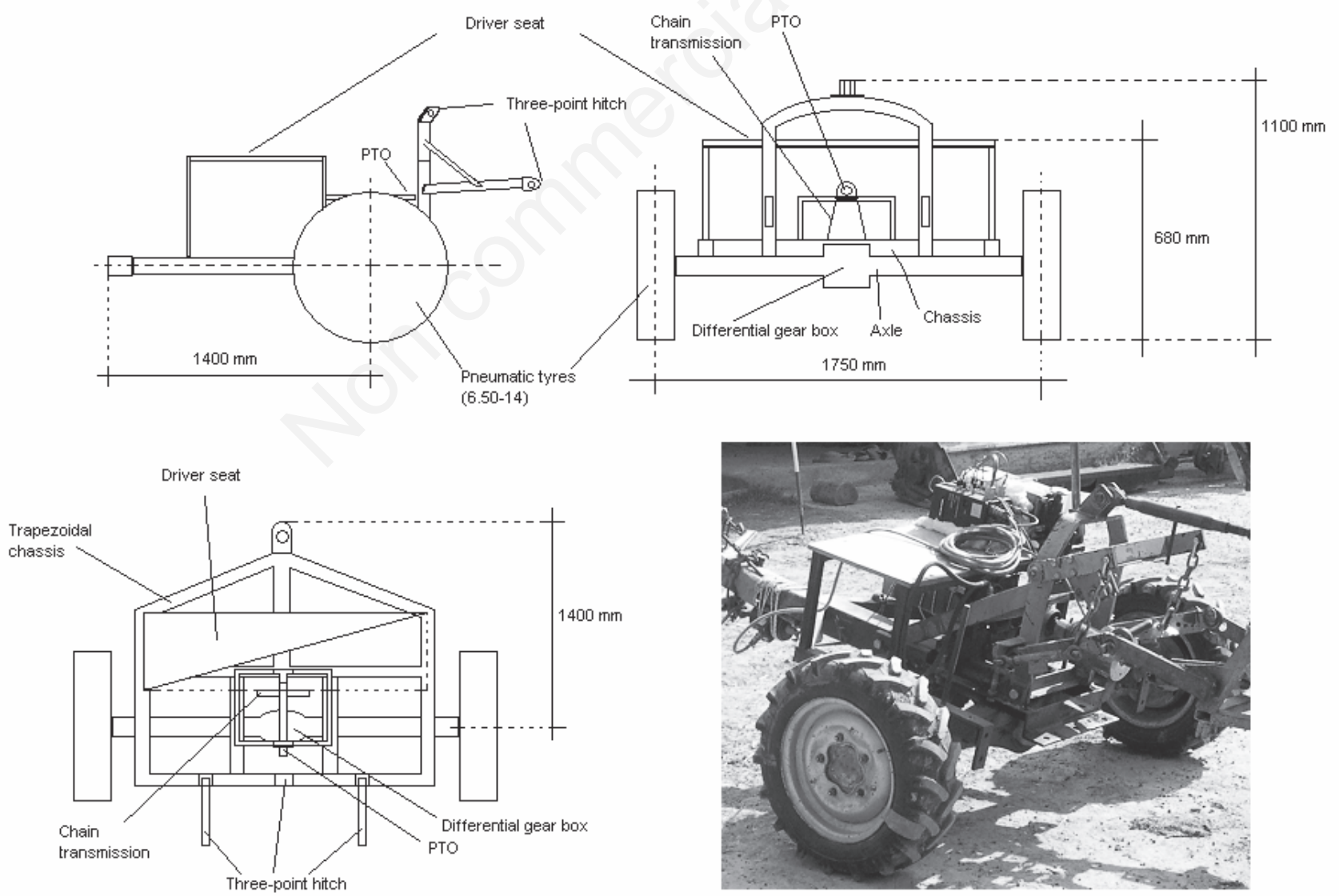

Figure 2. Schematic drawing of the driven hitch-cart structure. 
Slip efficiency has been computed as:

$\mathrm{SE}=1-\mathrm{S}$

where $s$ stay for slippage.

Slippage (s) has been computed according to:

$\mathrm{S}=\left(\mathrm{N}_{0}-\mathrm{N}_{1}\right) / \mathrm{N}_{0}$

where $\mathrm{N}_{1}$ is the observed number of wheel revolutions and $\mathrm{N}_{0}$ the theoretical number of wheel revolutions with no slip as derived from the wheel-rolling radius.

\section{Results and discussion}

Table 2 summarises the data recorded during draft trials. Draft force varies from a minimum of about $760 \mathrm{~N}$, corresponding to the pneumatic tires and the lowest ballast, up to about $4480 \mathrm{~N}$ with metallic wheels and the highest ballast. A linear increment of draft force as a function of the increasing PTO applied torque could be noticed (Figure 3).

Slippage rises as a function of the increasing torque, following an exponential fit ( $\mathrm{r}^{2}$ higher than 0.9 , data not showed). Consistently, PT0 speed linearly decrease as a function of rising torque, falling below 400 rpm at about torque values of $35 \mathrm{Nm}$ with pneumatic tires, regardless the ballast. The correspondent slippages are $29 \%$ and $22 \%$ at the lower and higher ballast, respectively. With metallic wheels this PTO speed value was reached over a torque value of about $49 \mathrm{Nm}$ (lower ballast) and $70 \mathrm{Nm}$ (higher ballast), corresponding to slippage of $30 \%$ and $58 \%$, respectively.
The requirement of pulling power follows the draft force, varying from about $0.860 \mathrm{~kW}$ (pneumatic tires and the lowest ballast), up to about $4.560 \mathrm{~kW}$ (metallic wheels and the highest ballast). Bearing in mind that a good draft horse is expected to weigh about $9000 \mathrm{~N}$ and that it can provide a pulling force of about $10 \%$ of its live weight, an available input power of $0.954 \mathrm{~kW}$ could be assumed for a single horse working at about $1.06 \mathrm{~m} \mathrm{~s}^{-1}$ (i.e., the overall average of forward speeds adopted in the present trials). This means that only 2 out of the 20 trials may be performed with a single horse, specifically cases 1 and 6 in

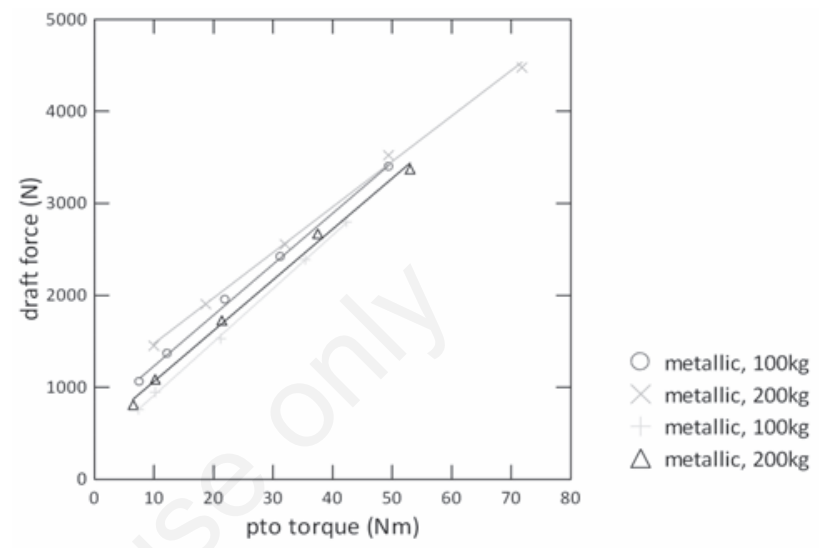

Figure 3. Linear relationship between required draft force and torque applied to power take-off at lower $(100 \mathrm{~kg})$ and higher $(200 \mathrm{~kg})$ ballast for metallic and pneumatic wheels $\left(\mathrm{r}^{2}\right.$ of linear fit are all higher than 0.99).

Table 2. Tractive responses of the driven hitch-cart draft trials.

\begin{tabular}{|c|c|c|c|c|c|c|c|c|c|c|}
\hline Trial & Wheels & $\begin{array}{l}\text { Ballast } \\
\text { (dan) }\end{array}$ & $\begin{array}{l}\text { Forward speed } \\
\qquad\left(\mathrm{m} \mathrm{s}^{-1}\right)\end{array}$ & $\begin{array}{c}\text { Draft force } \\
\text { (n) }\end{array}$ & $\begin{array}{l}\text { Torque } \\
\text { (nm) }\end{array}$ & $\begin{array}{l}\text { PTO speed } \\
\text { (rpm) }\end{array}$ & $\begin{array}{l}W_{\text {in }} \\
(\mathrm{kW})\end{array}$ & $\begin{array}{l}W_{\text {out }} \\
(\mathrm{kW})\end{array}$ & GE & $\mathrm{SE}$ \\
\hline 1 & Pneumatic & 98.1 & 1.13 & 759.1 & 7.4 & 526 & 0.858 & 0.408 & 0.48 & 0.90 \\
\hline 2 & Pneumatic & 98.1 & 1.13 & 945.7 & 10.2 & 544 & 1.069 & 0.581 & 0.54 & 0.92 \\
\hline 3 & Pneumatic & 98.1 & 1.12 & 1528.9 & 21.2 & 510 & 1.712 & 1.132 & 0.66 & 0.87 \\
\hline 4 & Pneumatic & 98.1 & 1.08 & 2387.8 & 35.4 & 402 & 2.579 & 1.490 & 0.58 & 0.71 \\
\hline 5 & Pneumatic & 98.1 & 1.07 & 2797.5 & 42.3 & 295 & 2.993 & 1.307 & 0.44 & 0.53 \\
\hline 6 & Pneumatic & 196.2 & 1.11 & 810 & 6.5 & 538 & 0.899 & 0.366 & 0.41 & 0.93 \\
\hline 7 & Pneumatic & 196.2 & 0.87 & 1724 & 21.4 & 411 & 1.500 & 0.921 & 0.61 & 0.90 \\
\hline 8 & Pneumatic & 196.2 & 0.93 & 1085 & 10.2 & 448 & 1.009 & 0.479 & 0.47 & 0.92 \\
\hline 9 & Pneumatic & 196.2 & 0.98 & 2669.3 & 37.5 & 399 & 2.616 & 1.567 & 0.60 & 0.78 \\
\hline 10 & Pneumatic & 196.2 & 0.91 & 3369 & 53.0 & 133 & 3.066 & 0.738 & 0.24 & 0.28 \\
\hline 11 & Metallic & 98.1 & 1.08 & 1056.3 & 7.6 & 519 & 1.141 & 0.413 & 0.36 & 0.94 \\
\hline 12 & Metallic & 98.1 & 1.12 & 1362.4 & 12.3 & 536 & 1.526 & 0.690 & 0.45 & 0.94 \\
\hline 13 & Metallic & 98.1 & 1.02 & 1948.6 & 22.0 & 473 & 1.988 & 1.090 & 0.55 & 0.91 \\
\hline 14 & Metallic & 98.1 & 1.06 & 2415.8 & 31.3 & 476 & 2.561 & 1.560 & 0.61 & 0.88 \\
\hline 15 & Metallic & 98.1 & 1.05 & 3394.8 & 49.5 & 375 & 3.565 & 1.944 & 0.55 & 0.70 \\
\hline 16 & Metallic & 196.2 & 1.15 & 1451.5 & 10.0 & 558 & 1.669 & 0.584 & 0.35 & 0.95 \\
\hline 17 & Metallic & 196.2 & 1.14 & 1903.3 & 18.7 & 547 & 2.170 & 1.071 & 0.49 & 0.94 \\
\hline 18 & Metallic & 196.2 & 1.06 & 3522.3 & 49.4 & 467 & 3.734 & 2.416 & 0.65 & 0.86 \\
\hline 19 & Metallic & 196.2 & 1.14 & 2552.4 & 32.0 & 518 & 2.910 & 1.736 & 0.60 & 0.89 \\
\hline 20 & Metallic & 196.2 & 1.02 & 4477.1 & 71.8 & 220 & 4.567 & 1.654 & 0.36 & 0.42 \\
\hline
\end{tabular}

PTO, power take-off; $W_{\text {in }}$, input power; $W_{\text {out }}$, output power; GE, global efficiency; $S E$, slippage efficiency. 


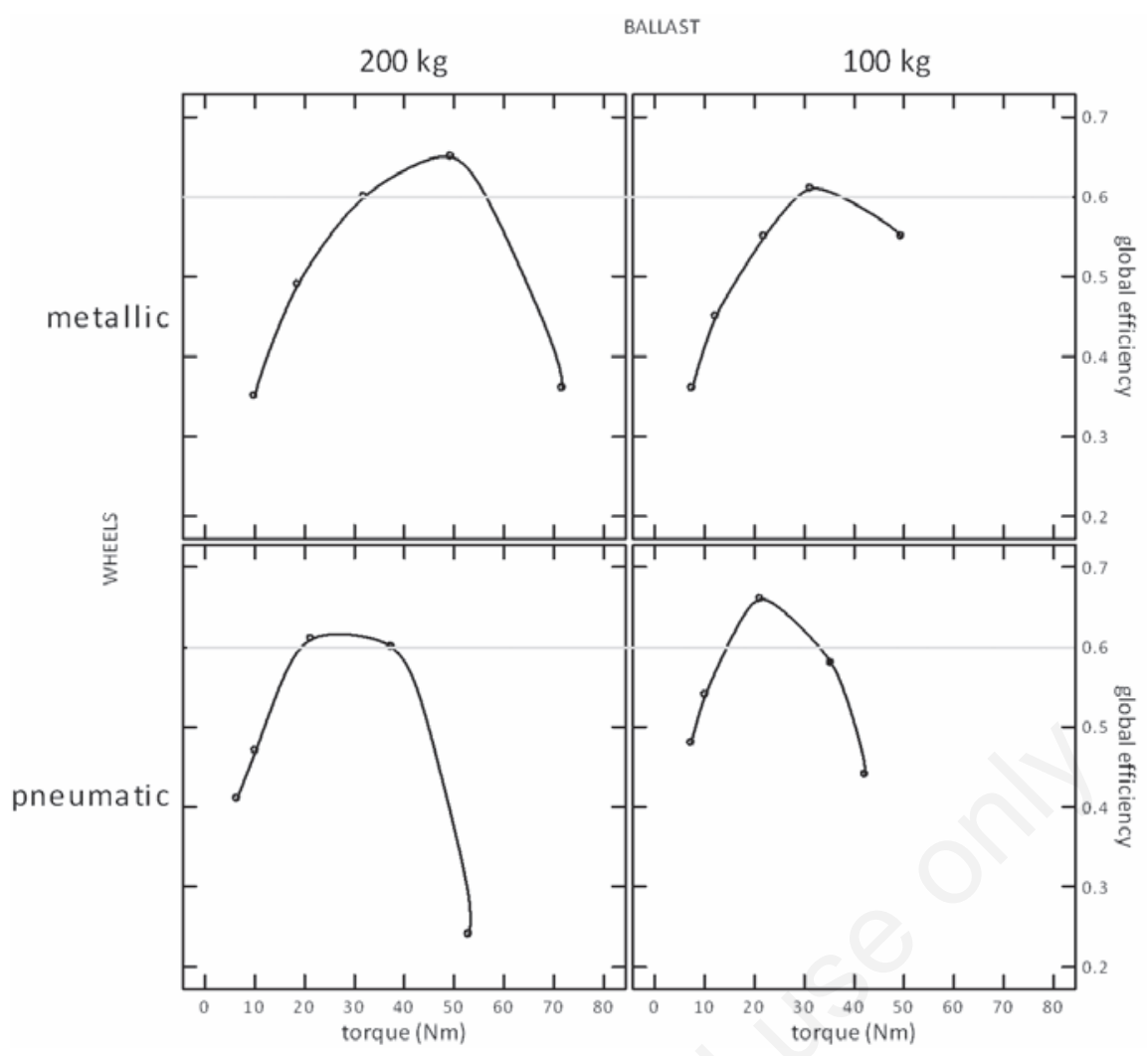

Figure 4. Global efficiency of the driven hitch-cart as a function of power take-off delivered torque, fitting different ballast load (100 $\mathrm{kg}$ and $200 \mathrm{~kg}$ ) and two kinds of wheels (pneumatic tires and metallic wheels).

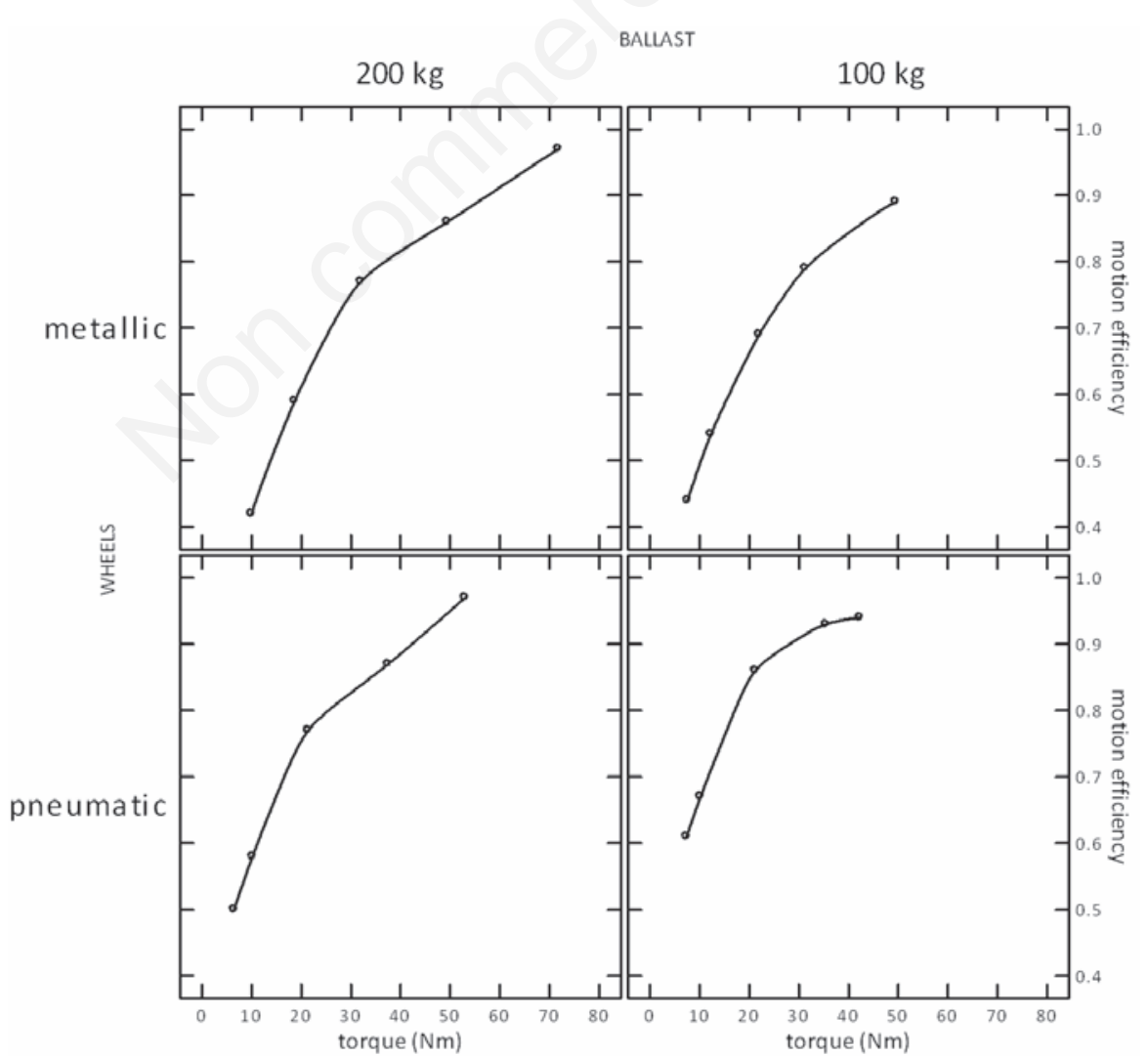

Figure 5. Motion efficiency of the driven hitch-cart as a function of power take-off delivered torque, fitting different ballast load (100 $\mathrm{kg}$ and $200 \mathrm{~kg}$ ) and two kinds of wheels (pneumatic tires and metallic wheels). 
Table 2, whereas in the remaining cases a team of horses should be used from 2 up to 5 animals. Further, useful information about the performances of the hitch-cart can be obtained by analysing the working efficiencies as a function of the PT0 applied torque (Figures 4-6). With regard to the global efficiency, a reference value of 0.6 can be assumed according to Wong (1978) as a good working performance. As showed in Figure 4, the peaks of the recorded global efficiencies exceed the 0.6 reference value in all the tested ballast-wheels combinations, spanning from 0.64 (metallic wheels at the lowest ballast and tires at the highest ballast) to 0.66 (metallic wheels at the highest ballast and tires at the lowest ballast). Global efficiencies were optimised at different torque values, specifically 24 and $40 \mathrm{Nm}$ for tires, and 30 and $50 \mathrm{Nm}$ for metallic wheels, at the lowest and highest ballast, respectively. Hence, despite the greater requirement in input power, metallic wheels, as well as increasing ballast, allow the global efficiency maximisation at greater PTO applied torque. Some final considerations can be drawn in view of the slippage efficiency showed in Figure 6. In fact, if we assume that for a proper working (i.e., do not waste energy merely to overcome rolling resistance) the extent of slippage should not exceed the limit of $20 \%$, with a global efficiency not below the limit of 0.6 , only 5 out of the 20 cases presented in Table 2 would be really applicable. These cases require a number of horses from 1 (cases 3 and 7, by pneumatic wheels and 100 and $200 \mathrm{~kg}$ ballast, respectively) to 3 (case 18, by metallic wheels and $200 \mathrm{~kg}$ ballast), to deliver a PT0 power from 0.9 to $2.4 \mathrm{~kW}$. Hence, the highest powers could be obtained only with metallic wheels and the highest ballast.

\section{Conclusions}

The results contribute to a better characterisation of the working performances of a wheeled tool-carrier designed for draft animal power. In general, the performances of the cart are consistent with the use of implements designed for small tractors or for motocultivators. The metallic wheels allow extending the range of use of the cart in terms of power available to the PTO with acceptable slippage.

Summarising: i) the draft force ranged between about $750 \mathrm{~N}$ and $4500 \mathrm{~N}$; ii) the available PTO power ranged from about $0.410 \mathrm{~kW}$ to $1.500 \mathrm{~kW}$ for pneumatic tyre, while from 0.410 to $2.400 \mathrm{~kW}$ for metallic wheel; iii) the best performance in term of global efficiency was 0.66 for pneumatic tyre obtained at about $20 \mathrm{Nm}$ torque and the lower ballast; for the metallic wheels the best performance was 0.65 obtained at about $50 \mathrm{Nm}$ torque and the higher ballast; iv) in our experimental conditions a threshold of about 30-35 Nm could be established from data; below this threshold pneumatic tires show better performances in term of GE, while over metallic wheels have better GEs.

Although simple in concept and developed several years ago for the realities of developing countries, this class of agricultural machines is still far from an optimised and performing design, fitting modern agricultural system of developed country. Several improvements of great potential could be implemented such as a system for dynamic balancing of the cart which allows balancing the weight of different mounted implements, or the introduction in the transmission drive-chain of a gearbox which allows adjusting the PTO speed as a function of animals' forward speed.

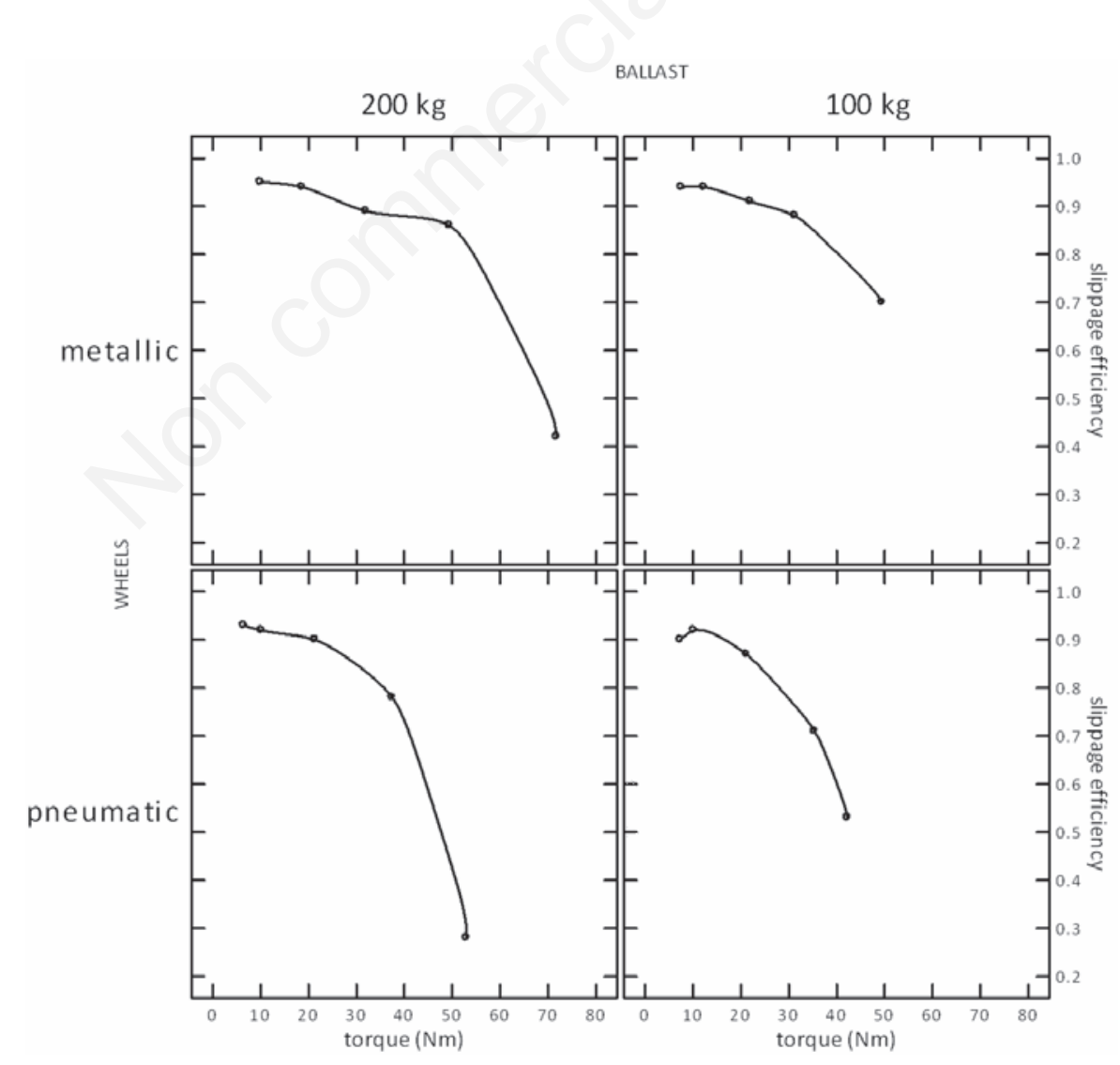

Figure 6. Slippage efficiency of the driven hitch-cart as a function of power take-off delivered torque, fitting different ballast load (100 $\mathrm{kg}$ and $200 \mathrm{~kg}$ ) and two kinds of wheels (pneumatic tires and metallic wheels). 


\section{References}

AGS (Rural Infrastructure and Agro-Industries Division). 2010. Draught animal power - an overview. FA0, Rome, Italy. Available from: http:/www.fao.org/fileadmin/user_upload/ags /publications/ draugth_ap_overview.pdf

Cerutti A.K., Calvo A., Bruun S. 2014. Comparison of the environmental performance of light mechanization and animal traction using a modular LCA approach. J. Clean. Prod. 64:396-403.

Fuller R.J., Aye L. 2012. Human and animal power - The forgotten renewable. Renew. Energy 48:326-32.

Joubert A.B.D. 2000. The horse-drawn hitch cart. Empowering farmers with animal traction. In: P.G. Kaumbutho, R.A. Pearson and T.E. Simalenga (Eds.), Proc. Workshop of the Animal Traction Network for Eastern and Southern Africa, 20-24 September 1999, ATNESA, Mpumalanga, South Africa, pp 213-218.

Leslie S. 2013. The new horse-powered farm: tools and systems for the small-scale sustainable market grower. Chelsea Green Publishing, White River Junction, VT, USA.
Mulder K., Dube B. 2014. Long-term ecological assessment of farming systems (LEAFS): comparing human, animal, and small machine power for fresh-market horticulture. Agroecol. Sustain. Food Syst. 38:704-21.

Mumma T. 2008. Draft animal power for farming. ATTRA - National Sustainable Agriculture Information Service. Available from: www.attra.ncat.org/attra-pub/draft_animal.html

Rydberg T., Jansén J. 2002. Comparison of horse and tractor traction using energy analysis. Ecological Eng. 19:13-28.

Spugnoli P., Dainelli R. 2013. Environmental comparison of draught animal and tractor power. Sustain. Sci. 8:61-72.

Spugnoli P., Parenti A., Masella P., Melani E. 2008. Test of an animal drawn field implement cart, J. Agric. Eng. 1:57-61.

Starkey P1988. Animal drawn wheeled toolcarriers: perfected yet rejected. GTZ, Eschborn and Vieweg, Braunschweig, Germany.

Stout B.A., Cheze B. 1999. CIGR handbook of agricultural engineering. Vol. III. ASAE, St. Joseph, USA.

Wong J.Y. 1978. Theory of ground veichles. J. Wiley \& Sons., Hoboken, NJ, USA. 